\title{
The Evolving Research on Intellectual Capital
}

\section{Hong Pew Tan}

The University of Western Australia,

\section{David Plowman}

The University of Western Australia, and

\section{Philip Hancock}

The University of Western Australia

\section{Contact Details:}

Philip Hancock

Associate Professor

UWA Business School

The University Of Western Australia

35 Stirling Highway, Crawley

WA 6009, Australia

Phone: +61 864881835 Fax: +61 864881072 E-mail: phancock@biz.uwa.edu.au

\begin{abstract}
:
This paper reviews the literature pertaining to developments in the field of Intellectual Capital (IC). Four areas are examined: definitions, models, measures and applications of IC to business and management issues. As an emerging field of study, IC has undergone a number of development stages. The first stage witnessed efforts to raise awareness of the importance and potential of IC. The second saw a consolidation of the concept that established research into IC as a legitimate undertaking. A subsequent stage sought appropriate measures of IC, and yet a further stage saw the applications of research and measures of IC to business and management issues.
\end{abstract}

Purpose - The purpose of the paper is to serve as a useful reference for anyone embarking on research into IC. It provides a succinct summary of the seminal works on this research area.

Design/methodology/approach - The paper reviews the seminal literature arranges it into a chronology of the evolving research into IC.

Findings - The findings show that IC has undergone a number of development stages from definitions, models through to measures and applications of IC to business and management issues. 
Research limitations/implications - The review is limited to refereed journals and books published before March 2007.

Practical implications - IC is an area of interest to numerous parties, including shareholders, institutional investors, scholars, policymakers and managers. This paper serves as a useful reference on the stages of development of IC and the applications to business and management issues.

Originality/value - The study of IC has undergone a number of stages, from early conscious awareness efforts, to classification of IC and to the search for appropriate measures of IC. This paper provides a taxonomy on IC research as suggestions about future research directions.

Key Words - Intellectual capital, definitions, measurement concepts, competitive advantage, applications of IC.

Paper type - Literature Review.

\section{Introduction}

Intellectual capital (IC) is the subject of increasing research by both academics and practitioners (Petty and Guthrie, 2000). It is also an area of increasing government interest and funding (OECD 1999, Meritum 2001). This paper examines the literature in four important IC areas: definitions, models, measures and its applications. These areas form the four substantive sections following this introduction. The last section is by way of summary.

\section{Definitions and Frameworks}

IC can be thought of as the knowledge-based equity of a company (IFAC, 1998). Though a relatively new area of investigation, Petty and Guthrie (2000) feel that there is growing acceptance of IC as a topic worthy of boardroom discussion and of serious academic investigation. The proliferation of conferences on IC; the myriad of books, working papers, and journal articles; and the large number of consulting firms offering products and services centred around IC, are testament to the growing awareness in the area (ibid.). While there is a general 
consensus on what constitutes IC, a universally accepted definition is still absent (Leon, 2002). One of the most workable definitions of is that offered by the OECD (1999) which describes IC as the economic value of two categories of intangible assets of a company:

1. Organisational ('structural') capital (SC); and

2. Human capital (HC).

More precisely, SC refers to things like proprietary software systems, distribution networks and supply chains. HC includes human resources within the organisation and resources external to the organisation - namely customers, partners and suppliers. Often, the term IC is treated as being synonymous with 'intangible assets'. The definition offered by the OECD, however, makes an appropriate distinction by locating IC as a subset, rather than the overall intangible asset base, of a business.

Stewart (1997, p. 75) defines IC as a composition of Human Capital (HC), Structural Capital (SC) and Customer Capital (CC). Roos et al. (1997) similarly classify IC into SC and HC which represents ‘thinking’ and ‘non-thinking’ assets. This distinction acknowledges different management methods for HC and SC. Another distinction has been suggested by Brooking (1996) who identifies four components of IC: market assets, human-centred assets, intellectual property assets and infrastructure assets. The difference between these classification systems is that they assume different levels of aggregation of the elements of IC. Most other classification schemes distinguish between external (customer related), internal structure and HC (e.g. Sveiby, 1997; Petrash, 1996). External structure concerns customer and supplier relations. Internal structure consists of patents, concepts, computer and administrative systems. The corporate culture of the company also belongs to the internal structure. HC refers to people's capacity to act in various situations. It includes skills, education, experience, values and motivation (Sveiby, 2001).

There are also a number of frameworks that have been developed. These are designed to better classify and study the elements of IC. Some of the more popular frameworks are the Balance Scorecard by Kaplan and Norton (1992), the Classifications of Resources by Haanes and 
Lowendahl (1997), the Intangible Asset Monitor by Sveiby (1997), the Skandia Value Scheme by Edvinsson and Malone (1997) and the Three Categories of 'Knowledge' by the Danish Confederation of Trade Unions (1999). These frameworks have been developed independently and at different times over the past decade. Many of them are conceptually similar. However, the major distinctions are the basic assumptions and classifications that lead to different levels of aggregation of the IC elements.

Roos et al. (1997) trace the theoretical roots of IC to two different streams of thought. The strategic stream is about classifying IC and its creation, management and utilisation. In order for IC to be managed and measured, the elements must first be categorised and understood. The measurement stream is about measuring and reporting of IC. Some of these models have been developed and tested in companies and provide for practical methods of measuring IC.

\section{Classifications and Conceptual Models Of IC}

The purpose of this section is to review the major works on classifying and conceptualising IC. It takes a chronological approach in order to highlight how the concept has evolved as newer researchers have built on earlier models.

The Value Platform model was developed in as a collaborative effort by Edvinsson (Skandia), Onge (The Mutual Group) and Petrash (Dow Chemical). The model classifies IC as:

$$
\text { Intellectual capital = human capital + organisational capital + customer capital }
$$

Figure 1 depicts the interrelationships amongst the three major components of IC. The dotted lines represent the management of the intellectual assets. The objective is to increase the number of inter-relationships so as to maximize the value space. The closer the interrelationships between human, organisational and customer capital, the larger the value space. 


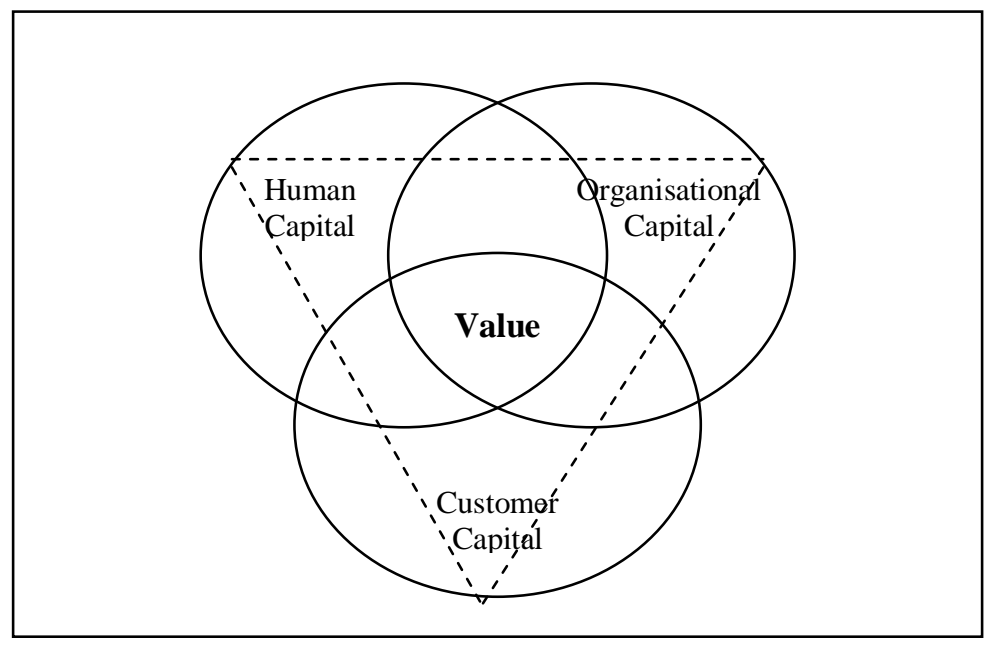

Figure 1 - The Value Platform Model (Petrash, 1996)

One of the first companies to report the 'intangibles' as business assets was Skandia AFS, a Swedish financial services company. In 1995, a supplement to Skandia's annual report used for the first time the word 'IC', instead of the accounting term 'intangible assets' (Edvinsson and Malone, 1997, p. 54). The Skandia Value Scheme is shown in Figure 2.

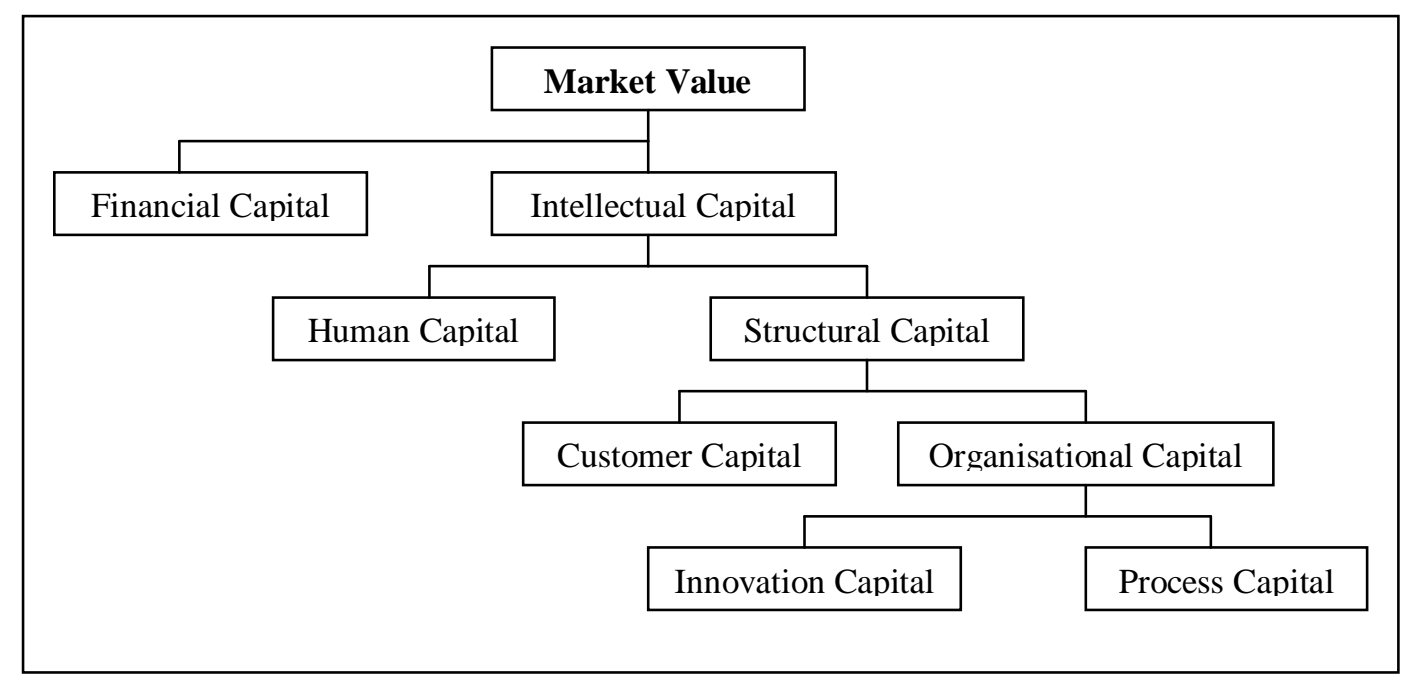

Figure 2 - The Skandia Value Scheme (Edvinsson and Malone, 1997, p. 52)

The Skandia Value Scheme, which was developed by Edvinsson in 1993, takes the market value of a firm as comprising the financial capital (inclusive of all tangible assets) and the IC (nonfinancial value). It further divides IC into SC and HC. SC includes customer and organisational capital that relates to the external and the internal focus of SC. Customer capital represents the external focus of the company and is a valuation of the customer relationships. 
Organisational capital consists of innovation and process capital. Process capital represents the know-how (for example, manuals and best practices) in the company. Innovation capital is that which creates success in the future and includes intellectual assets and intellectual property.

A different approach is the Classification of Resources approach adopted by Haanes and Lowendahl (1997) and Lowendahl (1997). This approach classifies a company's resources into tangible and intangible resources. This model is shown in Figure 3.

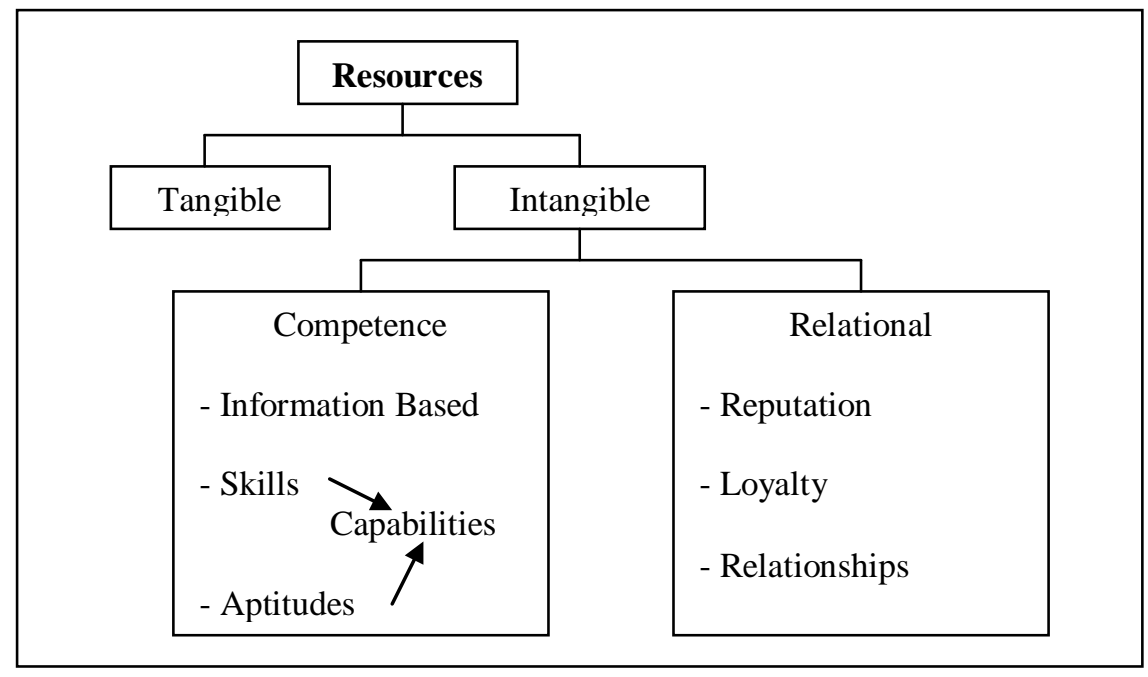

Figure 3 - The Haanes and Lowendahl Model (Haanes and Lowendahl, 1997)

Intangible resources are the IC of the company, which are further divided into competence and relational resources. Competence is the ability to perform a given task. It exists at two levels individual (knowledge, skills, aptitude or capabilities) and organisational (information based like databases, technology and procedures). Relational resource refers to the reputation of the company, client loyalty and the relationships it has with customers.

Lowendahl (1997) further divides the competence and relational categories into two subgroups, Individual and Collective, depending on whether the resource is employee or organisationally focused (See Figure 4). This added division distinguishes between IC that is people-dependent and IC that is organisational-dependent. 


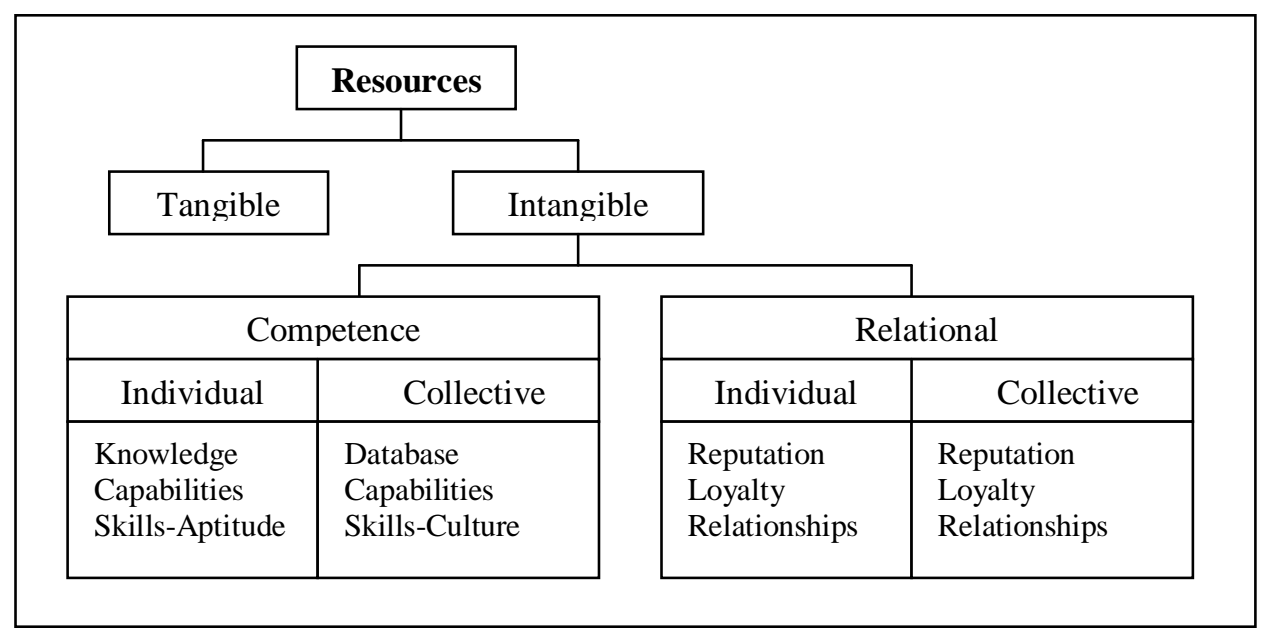

Figure 4 - The Lowendahl Model (Lowendahl, 1997)

Stewart (1997, p. 75) uses a different conceptual scheme and divides IC into three basic forms: Human Capital (HC), Structural Capital (SC), and Customer Capital (CC). HC is the accumulated capabilities of individuals responsible for providing customer solutions. SC refers to the capabilities of the organisation to meet market requirements. Unlike HC, SC can be formally captured and embedded. CC points to the extent and intensity of the organisation's relationships with customers. The three types are interrelated - each one positively or negatively affecting the other. Figure 5 shows the components of IC espoused by Stewart.

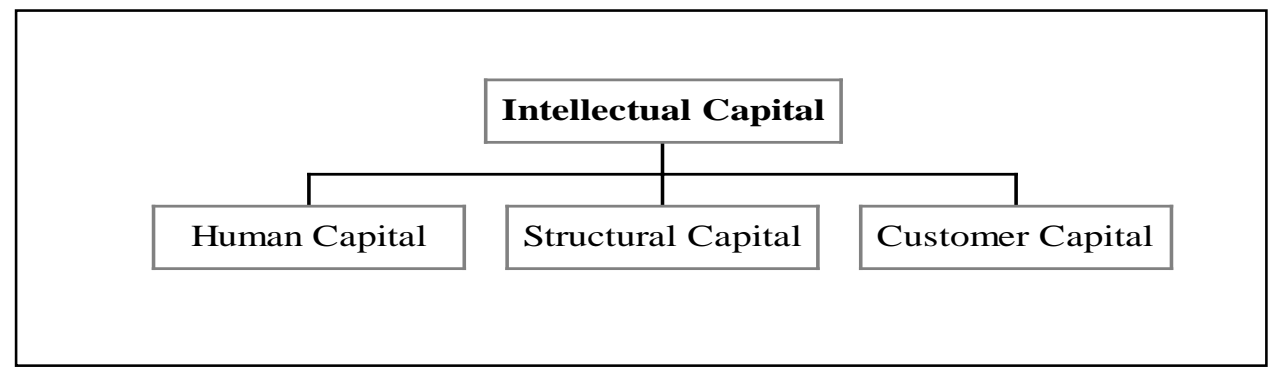

Figure 5 - Components of Intellectual Capital (Stewart, 1997)

A further model to help understand IC is the framework developed by the Danish Confederation of Trade Unions (1999). This is shown in Figure 6. 


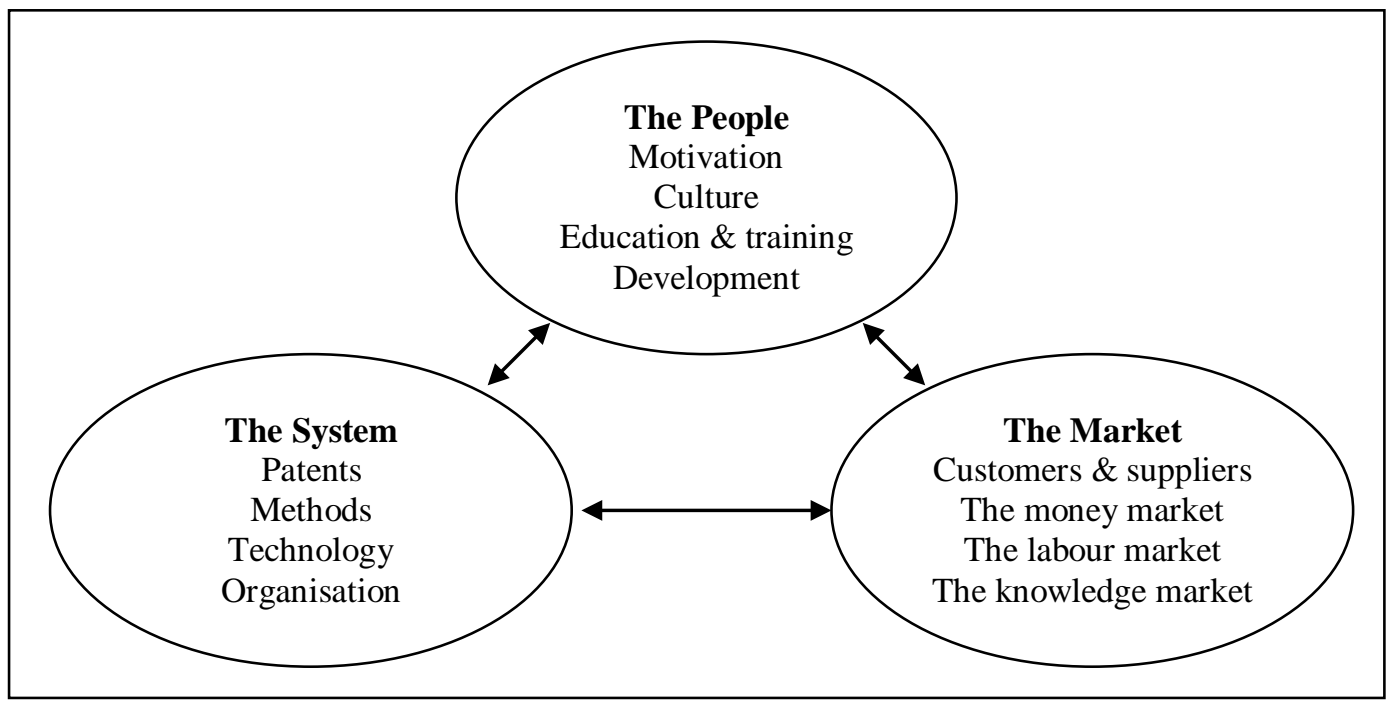

Figure 6 - The Danish Confederation of Trade Unions Model (DCTU, 1997)

'The People' element represents employee and managers' competence, both individually and collectively. The model suggests that this element is dependent on people's motivation, their culture, their education and their training and development. 'The System' is the knowledge in the company that is independent of people. It includes patents, methods, technology and the organisation of the company. 'The Market' consists of the relationships between the organisation and outsiders including suppliers, partners, distributors and customers. 'The Market' is also a source of money, labour and knowledge that the company lacks. These three categories of IC are closely intertwined. For example, the success of new technology (part of Systems) is dependent on staff competence and training (part of People).

Between November 1998 and April 2001, the European Community funded the Meritum Project (Meritum, 2001). Meritum is an acronym for 'Measuring Intangibles to Understand and Improve Innovation Management’. The aim of this project is to improve the policy-making capabilities of the European Community in the realm of science and technology policy particularly in respect to innovation, by providing a consistent basis for the reliable measurement of intangibles investments (ibid). Meritum classifies IC as HC, SC and relationship capital. Although Meritum uses the term 'relationship capital', the definition is similar to Stewart's customer capital. 
Leliaert et al. (2003) propose a 4-Leaf Model. The four IC classes are listed as human capital (HC), customer capital (CC), strategic alliance capital (SA) and structural capital (SC) - each of which is represented by one leaf in the model. They argue that these classes overlap to yield 15 distinct IC sections as shown in Figure 7. These may then be grouped in three IC categories: (1) Structuralized capital; (2) Non-structuralized internal capital; and (3) Non-structuralized external intellectual capital.

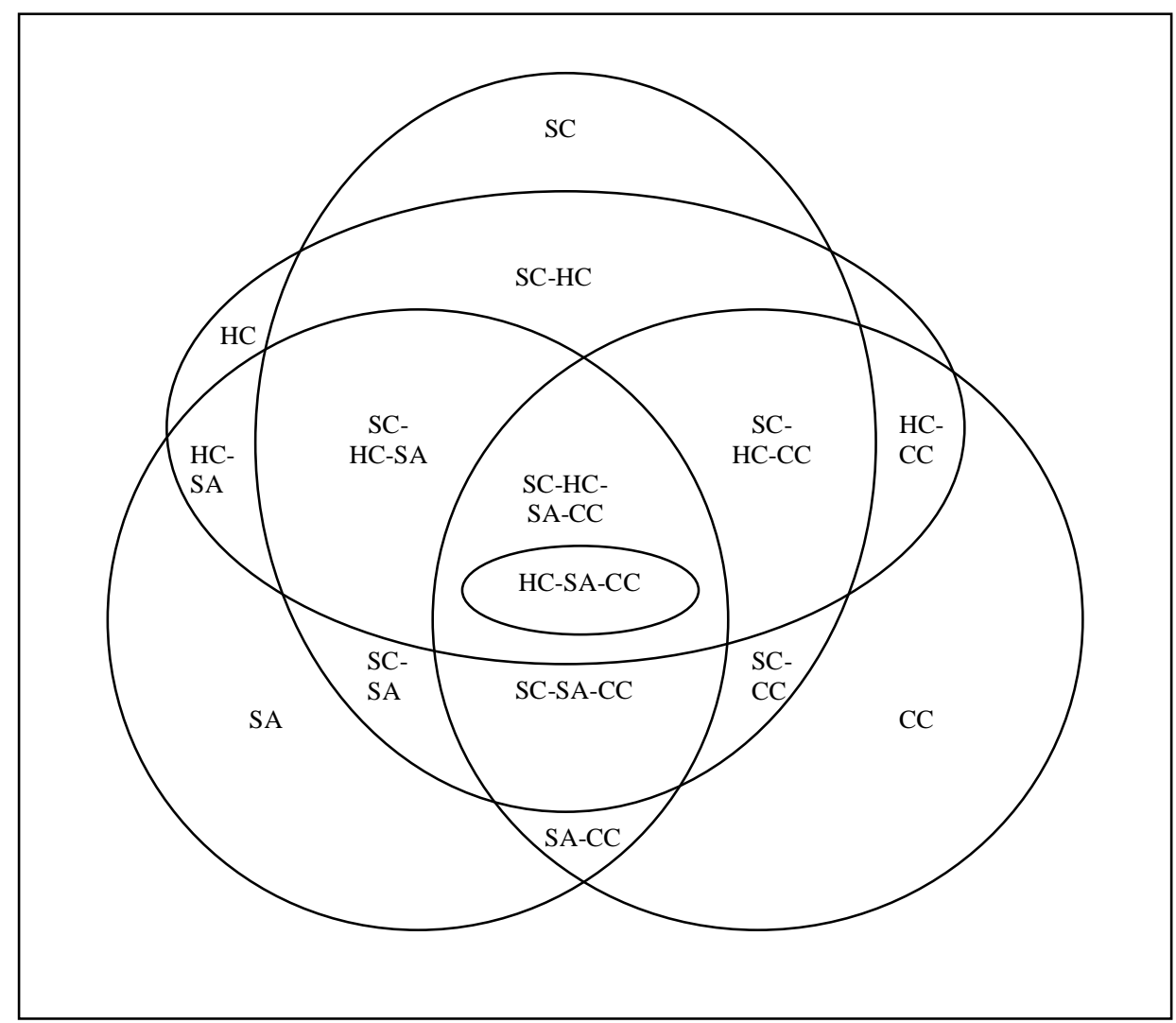

Figure 7 - The 4-Leaf Model (Leliaert et al. 2003)

\section{Measurements}

It has been stated that if one cannot measure, one cannot manage (Liebowitz and Ching, 2000). Lord Kelvin once said:

When you can measure what you are speaking about and express it in numbers, you know something about it; but when you cannot measure, when you cannot express in numbers, your knowledge is of a meagre and unsatisfactory kind. It may be the 
beginnings of knowledge, but you have scarcely, in your thoughts, advanced to the stage of a science (ibid).

The statement stresses the importance of measuring concepts. The lack of a generally accepted methodology for valuing intangible assets has led to numerous efforts. Sveiby (2002) suggests that measuring approaches for intangibles fall into four categories. These categories are an extension of the classifications suggested by Luthy (1998) and Williams (2000), namely::

- Direct Intellectual Capital Methods (DIC). This method estimates the dollar value of intangible assets by identifying its various components. Once these components are identified, they can be directly evaluated, either individually or as an aggregated coefficient.

- $\quad$ Market Capitalization Methods (MCM). MCM calculates the difference between a company's market capitalization and the book value of its shareholders' equity as the value of its IC or intangible assets.

- $\quad$ Return-On-Assets (ROA) Methods. ROA method is the average pre-tax earnings of a company for a period of time divided by the average tangible assets of the company. The result is a company ROA that is then compared with its industry average. The difference is multiplied by the company's average tangible assets to calculate an average annual earning from the intangibles. Dividing the above average earnings by the company's average cost of capital or an interest rate, one can derive an estimate of the value of its intangible assets or IC.

- Scorecard Methods (SCM). The various components of intangible assets or IC are identified and indicators and indices are generated and reported in scorecards or as graphs. SCM methods are similar to DIC methods, except that no estimate is made of the dollar value of the intangible assets. A composite index may or may not be produced.

Sveiby (2002) suggests that different measurement methods offer different advantages. The financial methods that offer dollar valuation, such as ROA and MCM, are useful in merger and acquisition situations and for stock market valuations. They can also be used for comparisons 
between companies within the same industry and they are good for illustrating the financial value of IC. The advantages of the DIS and SCM methods are that they can create a more comprehensive picture of a company's health than financial metrics, and that they can be easily applied at any level of a company. They measure closer to an event and reporting can therefore be faster and more accurate than purely financial measures (ibid, 2002).

For this review, measuring methods are grouped broadly under two categories namely: 'NonDollar Valuation of IC' and 'Dollar Valuation of IC'. Non-Dollar Valuation of IC does not offer dollar valuation while Dollar Valuation of IC estimates the dollar values of IC. The following represents a selective, rather than exhaustive, list of measuring systems.

\subsection{Non-Dollar Valuation of IC}

A pioneering model is that proposed by Kaplan and Norton (1992). This utilises the balanced scorecard that measures organisational performance across four linked perspectives: financial, customer, internal business processes, and learning and growth. This is shown in Figure 8. 


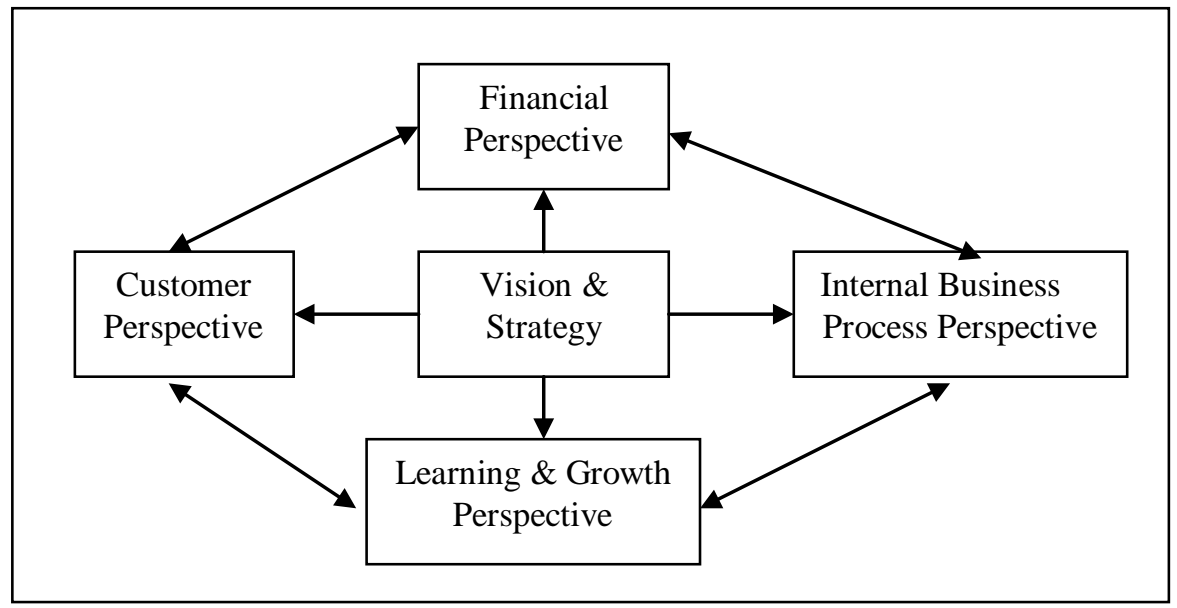

Figure 8 - The Balanced Scorecard (Kaplan and Norton, 1992)

The balanced scorecard represents a set of cause-and-effect relationships amongst output measures and performance drivers. It provides for the control of intangibles while simultaneously monitoring financial results. The balanced scorecard allows management to look at the organisation from four important perspectives which for a company are:

1. How do customers view the company?

2. What must the company excel at?

3. Can the company continue to improve and create value?

4. How does the company look to shareholders?

This IC measurement system is very company-specific. Furthermore, it is not able to assign a financial value for the intellectual assets in an objective manner. For these reasons, it may not have general application.

Brooking (1996) has suggested three measurement models to help measure the value of IC. He defines IC as the combined amalgam of four components: market assets, human-centred assets, intellectual property assets and infrastructure assets. Using the Technology Brokers’ IC audit, Brooking begins the diagnostic process by having organisations answer 20 questions that make up an IC indicator. The results suggest that the less a company is able to answer in the affirmative, the more it needs to focus on strengthening its IC. The Technology Broker 
approach has been lauded for offering a toolbox for organisations to assign value to IC. Lynn (1998) suggests that Brooking has created an IC audit that itself represents an intellectual asset for organisations. However, the main weakness in this measure is the considerable leap that must be made from the qualitative results of the questionnaire to actual dollar values for these assets (Bontis, 2001).

Another measure is the Skandia IC report or Navigator Model. This uses 112 metrics to measure five areas of focus (Edvinsson and Malone, 1997, p. 68). The five areas are shown in Figure 9, namely: financial, customer, human, process and renewal and development. The financial focus consists mainly the company's balance sheet that deals with the past of the firm. Customer, human and the process focus constitute the IC of a firm and represent the present stage of the firm. Renewal and development is the foundation that underpins the company's future. The 112 indices are computed using direct counts, dollar amounts, and percentages or survey results as appropriate. Some examples of these indices are: Income per employee, value added per customer and invoicing per employee.

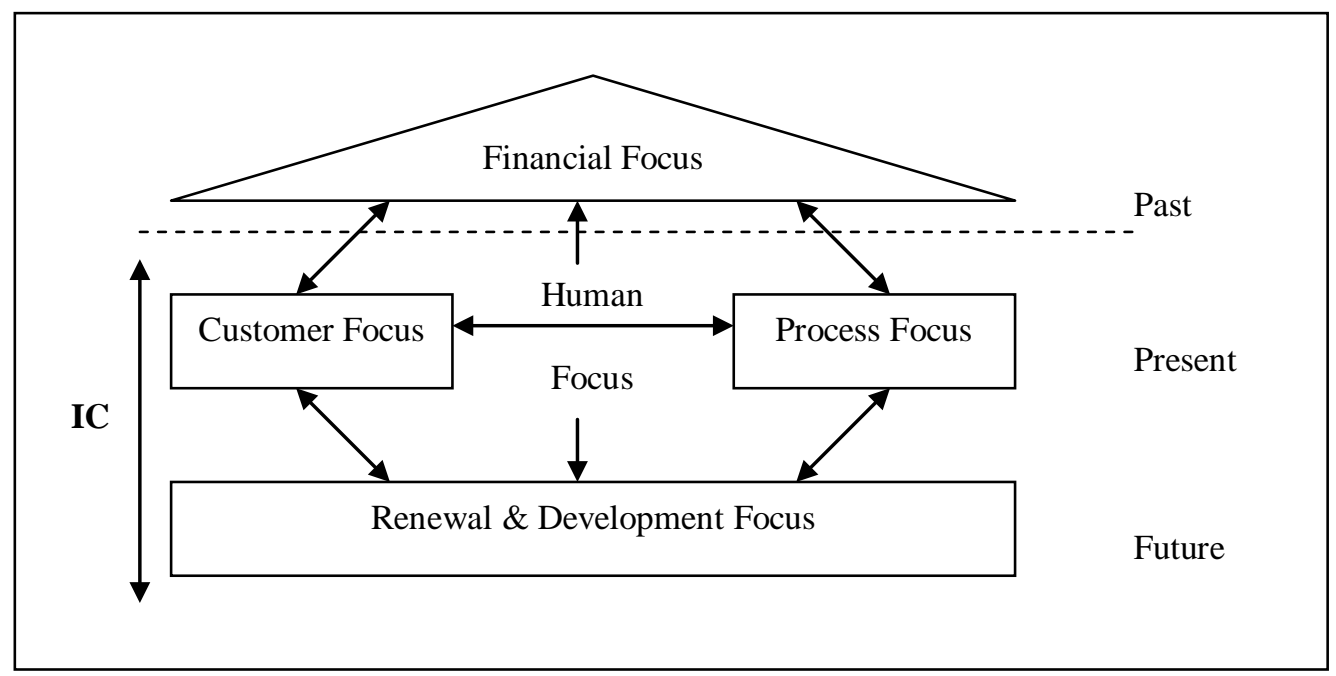

Figure 9 - The Skandia Navigator (Edvinsson and Malone, 1992, p. 68)

Most researchers agree that Skandia's considerable efforts to create a taxonomy that measures a company's intangible assets has motivated others to look beyond traditional assumptions of what creates value for organisations (Bontis, 2001). Skandia's model is particularly impressive in recognising the role of $\mathrm{CC}$ in creating value, and how the nature of customer relationships 
has changed. Skandia's model also provides a broad coverage of organisational structural and process factors. Its focus on process, renewal and development contributions to organisational value has not been previously attempted. However, Lynn (1998) notes that Skandia assigns no dollar values to its IC. Instead it uses proxy measures of IC to track trends in the assumed value added.

Roos et al. (1997) have examined the assumptions underlying three of Skandia's metrics and are able to offer plausible alternative interpretations about what each metric might represent for an organisation. As a result, they conclude that every company will need to possess a unique understanding of which intangible assets are truly valuable for the organisation. Thus, each organisation must choose which assumption is most valid for its case and identify the appropriate metrics. In short, the Skandia's IC method of measurement suffers from problems of subjectivity.

The IC-Index is an example of 'second generation' measures that attempts to consolidate all the different individual indicators into a single index and to correlate the changes in IC with changes in the market (Roos et al., 1997). The notion of an IC-Index, originally advanced by Goran Roos was used in the first place by Skandia in its 1995 IC supplement to its Annual Report. Since Skandia's adoption, the logic of an IC-Index has been endorsed and implemented by many other practitioners. According to Roos et al. (1997), the IC-Index has several distinct features:

- $\quad$ it focuses on monitoring of the dynamics of IC;

- $\quad$ it is capable of taking into account performance from prior periods;

- $\quad$ it provides a different perspective to the typical valuation based on an examination of physical assets;

- $\quad$ it is a self-correcting index in that if performance of the IC-Index does not reflect changes in the market value of the company, then the choice of capital forms, weights and/or indicators is flawed.

Roos et al. (1997) propose that company-specific IC measures can be decided by knowing the company's strategy, the characteristics of the company business and its day-to-day operations. However, an IC-Index is very much context-specific and is therefore limited in its universal 
applications. Different definitions, strategic prioritising, choice of indicators and other elements all limit the value of comparisons of IC-Indexes between companies (Bontis, 2001). In addition, since only proxy measures are taken of IC stock, all metrics are dimensionless, ordinal numbers (Roos et al., 1997). Like many other measures of intangible assets, an IC-Index depends on value judgements in the choice of weights and indicators. Despite this charge of subjectivity, Roos et al. (1997) argue that the IC measurement, and especially a consolidated measure such as the IC-Index, makes a larger part of the organisation visible and open to valuation. Also, since IC-Index takes past performance into account, it is subjected to 'one-off special events' which can have a strong influence on moving the index up or down for some years after an event (Bontis, 2001).

In the Intangible Asset Monitor, Sveiby (1997) proposes a framework developed from the 'invisible balance sheet'. Invisible assets are matched on the financing side of the balance sheet by equally invisible finance, most of which are in the form of invisible equity. The Intangible Asset Monitor model classifies IC into the three categories: internal structure, external structure, and individual competence. Internal structure consists of both the formal and informal culture within the organisation. External structure comprises the relationships between the organisation and others such as customers, suppliers, brand names, trademarks and reputation. Individual competence refers to people's capacity to act in various situations. It includes patents, concepts, models, databases and internal systems. In his conceptual model, Sveiby identifies three measurement indicators: growth/renewal, efficiency and stability for each of the three intangible assets. Some companies have used this method for measuring and monitoring its knowledge assets but have found it difficult to assign monetary financial values to the final measure (Bontis, 2001).

Joia (2000) expands on the research carried out by Edvinsson and Malone (1997), Roos et al. (1997), Sveiby (1997) and Stewart (1997). He proposes a variation of market-to-book value and develops a new formula: Intellectual Capital $=$ Human Capital + Innovation Capital + Process Capital + Relationship Capital. Joia claims that within a heuristic framework there is 
room for a wide range of more specific formulations, but also enough structure to guide and focus discussion. However, this formula includes esoteric variables that are difficult to define operationally and measure objectively.

Vanderkaay (2000) proposes a ‘Vital Sign’ scorecard. These vital signs can be used to identify the most basic corporate fitness level required to compete in a knowledge-intensive world. Vanderkaay contends that many IC measurement tools place disproportionate emphasis on what is easy to quantify, rather than what is critical to a firm's survival. For example, a company may be pre-occupied with the number of ideas in its knowledge management database and be completely unmindful of the destruction of its IC as the result of oppressive office politics. In this instance, a relative measure (for example, a one out of ten rating under vital sign \#3, 'Great place to work') provides more essential information than determining the size of the database (ibid.). There are ten questions in the Vital Sign scorecard and this is shown in Figure 10.

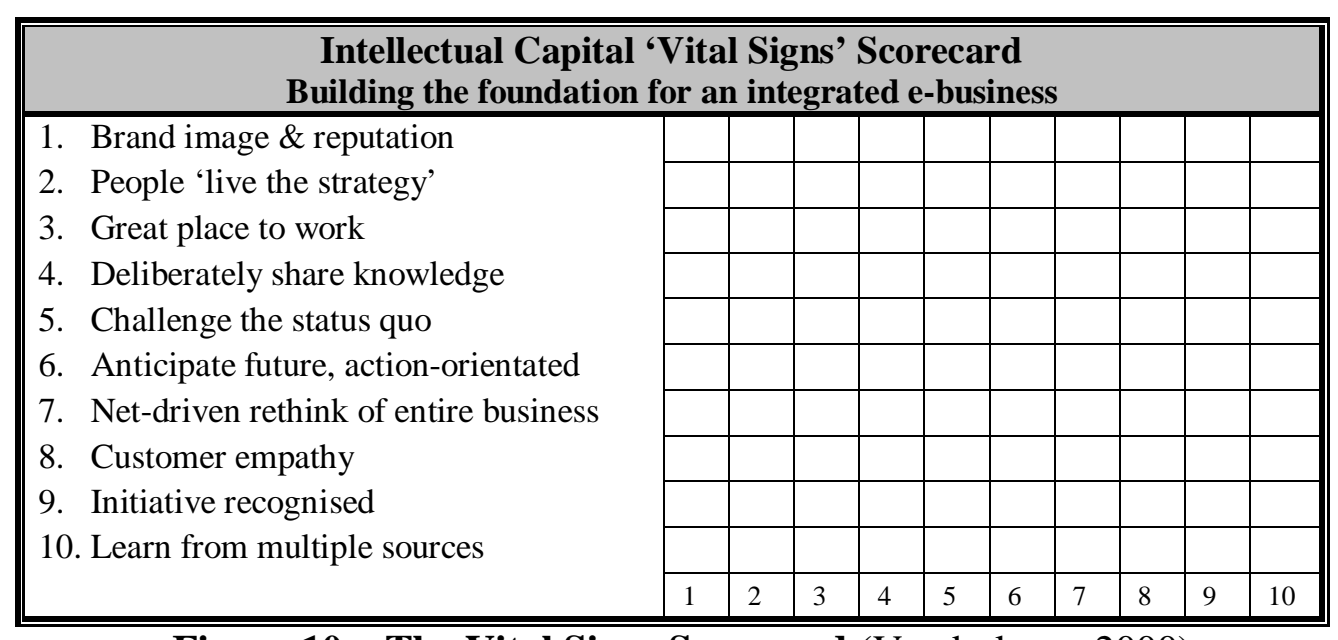

Figure 10 - The Vital Signs Scorecard (Vanderkaay, 2000)

The questions in the scorecard are reminiscent of an employee satisfaction survey. They are probably more suitable as a gauge of employee satisfaction level than as a true measure of IC.

Barsky and Marchant (2000) highlight an Ernst \& Young study of financial analysts that identifies the ten most important non-financial measures to investors-metrics that can be integrated into management reporting and evaluation systems. The ten metrics are shown in Figure 11: 


\section{Ernst \& Young Metrics}

1. Strategy education.

2. Management credibility.

3. Quality of strategy.

4. Innovation.

5. Ability to attract talented people.

6. Market share.

7. Management expertise.

8. Quality of executive compensation.

9. Quality of major processes.

10. Research leadership.

Figure 11 - The Vital Signs Scorecard (Barsky \& Marchant, 2000)

These measures reinforce the view that intellectual resources, not products, constitute the primary source of competitive advantage. However, except for market share, the metrics are subjective and not easily quantifiable. Thus, such a measure for IC will be difficult to apply across different companies.

Mouritsen et al. (2002) explore how IC is formed and made organisationally relevant. They undertook a longitudinal study of seventeen firms' work to develop IC statements over three years. They followed the translations made from initial 'good idea' to two documents called IC statements. They studied the IC as it was unfolding and look at how it gradually became strong from initially fragile potentialities. The study is concerned with how IC is stabilised, made productive and potent and becomes a key to the firm's construction of its strategy for managing 'intellectual resources'. They did this by interviews, observing the firms over three years, and participating in progress workshops.

Mouritsen et al. (2002) argue and illustrate that the object of IC statements is knowledge management activities. The IC statement is a document that combines various kinds of resources and activities. Thus it combines knowledge narrative and a monitoring system to form an index of the progress of knowledge management activities. A weakness of this method is that it does not provide an objective way to quantify and measure IC. For this reason, it is difficult to replicate across companies. 
Kannan and Aulbur (2004) propose a three-step model for IC measurement shown in Figure 12. The three steps include: identification and awareness, systems and output measures, and outcome measures of tangible financial returns. The first step Knowledge Management Awareness measures the organization’s awareness and readiness for knowledge management, as well as the extent of employee and management involvement. This stage also identifies corecompetencies, establishes knowledge criticality, and includes culture audits. In the second stage, existing system and process effectiveness is measured. This measurement includes existing frameworks (for examplegoal-question paradigm), process efficiency measures and usability statistics. This step involves a current status assessment, and indicators for future enhancement or change. In the third stage, the processes and systems are linked to basic effectiveness standards and financial and social outcomes.

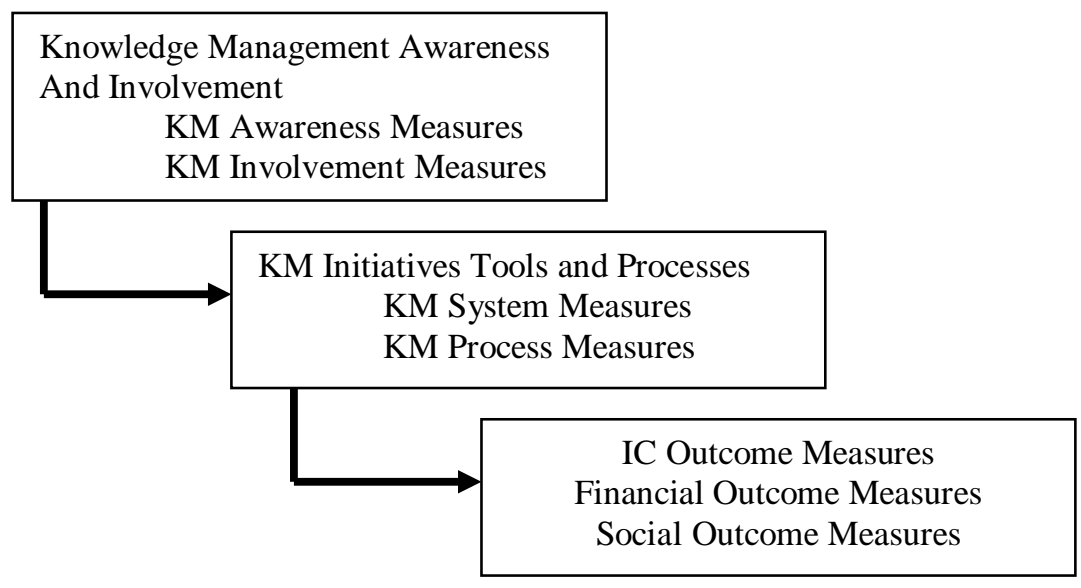

Figure 12 - Three-Step Model (Kannan \& Aulbur 2004)

Jacobsen et al. (2005) introduce the IC Rating ${ }^{\mathrm{TM}}$ approach as a management consulting approach to measure IC and to report on the implementation and experience in one case study of a firm. The paper describes the IC Rating ${ }^{\mathrm{TM}}$ model in the context of the exiting literature in the field of IC measurement and uses a case study to demonstrate its practical application. Based on the presented case study as well as implementations in other organizations, they find the IC Rating $^{\text {TM }}$ model a useful tool to facilitate the analysis and discussion about IC in organizations. Figure 13 shows the IC Rating ${ }^{\mathrm{TM}}$ model.

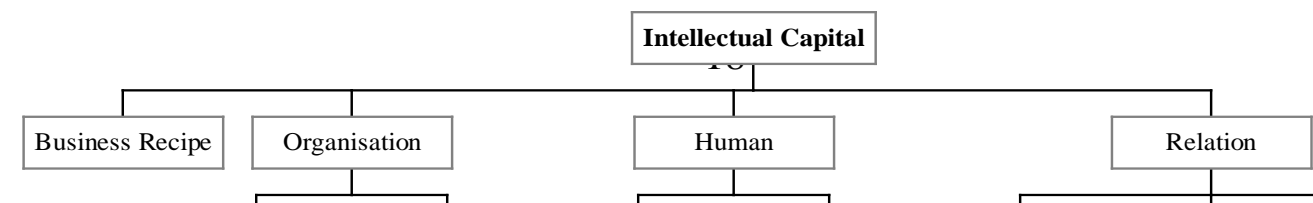


Figure 13 - IC Rating ${ }^{\mathrm{TM}}$ Model (Jacobsen et al. 2005)

Oliver and Porta (2006) present a theoretical cluster strategic framework for IC measurement. Design methodology was used to construct a model which achieves the aforementioned purpose. The paper provides a comprehensive model to describe, map, measure and value IC in clusters and systematically control the IC evolution. However, the system provided is not an exhaustive use of all the available measures. A more comprehensive practical application on several clusters would be necessary to validate and re-adapt the model.

\subsection{Dollar Valuation of IC}

Economic Value Added (EVA) was introduced by Stem Stewart as a comprehensive performance measure that uses the variables of capital budgeting, financial planning, goal setting, performance measurement, shareholder communication and incentive compensation to account properly for all ways in which corporate value can be added or lost (Bontis et al., 1999). EVA concentrates on maximising incremental earnings over capital costs. By contrast, the Market Value Added (MVA) represents the spread between the cash that a firm's investors have put into the business since the start up of the company and the present value of the cash that they can get out of it by selling their shares.

EVA is intended to offer improvements to the MVA calculation (ibid.). However, in terms of its use as a surrogate measure of IC, Bontis et al. (1999) note that if EVA is used, it implies that no specific measures of intangible assets are needed. Three other limitations in the calculations used to create EVA include: the use of book assets relies on historical costs which give little indication of current market value or replacement cost; empirical research has not shown conclusively that EVA is a better predictor of stock price or its variation; and the starting point for EVA analysis assumes that companies should be operate exclusively for the benefit of its 
shareholders. In sum, the EVA performance measure may not be appropriate when attempting to quantify the value of intangible assets.

Another widely known indicator of the IC is the market-to-book value comparison (Dzinkowski, 2000; Lev and Feng, 2001; Guthrie, 2001; Seetharaman et al., 2002). Stewart (1997) and Edvinsson and Malone (1997) argue that the value of a firm's IC can be represented by the difference between the book value and the market value of the firm. They assume that Market Value $=$ Book Value + Intellectual Capital. However, this value will then be subjected to variations in the book value of the physical assets, their current market price and various imperfections that may exist in market valuations. Any fluctuations in share price will lead to a corresponding change in IC, even though nothing has fundamentally changed in the company. Stock prices are, at times, affected by many economic factors not associated with a company's tangible assets or IC (Luthy, 1998). Calculations of IC that use the difference between market and book values can also suffer from inaccuracy because book values can be impacted by many factors including for example, if firms choose to, or are required to, revalue property or adopt tax depreciation rates for accounting purposes (Dzinkowski, 2000). Lev and Feng (2001) also reject this measure of knowledge assets. They assert that 'The most egregious of this crude measure is that the number rises and falls with market exuberance'.

Luthy (1998) highlights the use of Tobin's q method to measure IC. Tobin's q measure can help to predict investment decisions. Tobin's q is essentially the same as the market-to-book ratio except that it uses replacement cost of tangible assets rather than book value of tangible assets in the calculation. The theory is that if q is greater than 1 and greater than competitors' q, then the company has the ability to produce higher profits than similarly placed companies. The company has something intangible (or IC) that gives it an advantage over competitors. Tobin's q can be calculated by taking the book value of a company, adding back accumulated depreciation and making appropriate adjustments for price changes in different classes of assets from the time of purchase. This procedure is an improvement of the market-to-book value, but still faces the same difficulties regarding volatile stock prices. 
Pulic (1998 and 2000) develops the 'Value Added Intellectual Coefficient' (VAICTM) to measure the IC of companies. The model starts with a company's ability to create value added (VA). VA is the difference between sales (OUT) and inputs (IN):

$$
\text { OUT }- \text { IN }=\text { VA }
$$

Outputs (OUT) represent the income and comprise all the products, services and assets sold on the market. Inputs (IN) contain all the expenses covering everything that come into the company except manpower costs. The result is value added (VA) expressing the new created wealth of a period. The second relation of VA, one employing physical capital (CA) is called 'Value Added Capital Coefficient' (VACA). This is an indicator for the VA created by one unit of physical capital.

$$
\mathrm{VACA}=\mathrm{VA} / \mathrm{CA}
$$

The 'Human Capital Coefficient' (VAHU) shows how much VA is created by a dollar spent on employees.

$$
\mathrm{VA} / \mathrm{HC}=\mathrm{VAHU}
$$

The relation between VA and HC indicates the ability of HC to create value in a company. The next step is to find out the contribution of SC in value creation. In Pulic's model, SC is VA minus HC. HC and SC are inversely proportional. STVA measures the share of SC in the creation of VA. The third relation between VA and SC is calculated as:

$$
\mathrm{SC} / \mathrm{VA}=\mathrm{STVA}
$$

The final step is the calculation of the intellectual ability of a company. It is the sum of previously mentioned coefficients which results in a new and unique indicator - the VAIC ${ }^{\text {TM }}$

According to Dzinkowski (2000), a measure called ‘Calculated Intangible Value’ (CIV) has been developed by NCI Research ${ }^{1}$ to calculate the fair market value of the intangible assets of the firm. The methodology follows Revenue Ruling 680609 of the United States Internal Revenue Service. The CIV calculates the excess return on hard assets and uses this calculation as a basis for determining the proportion of return attributable to intangible assets. Although the 
CIV gives an indication of the value-add of the company in providing return on the tangible assets, it does not distinguish between physical and financial assets. When lumped together as total tangible assets, the model also assigns the same rate of return for both physical and financial assets. This reduces the usefulness of the measure. It does not reflect market realities nor allow for a separate measure of the IC contribution to a company's value.

Lev and Feng (2001) develop yet another measure for the IC of firms. They have broken with accounting tradition and his approach allows one to infer a dollar value for almost any company's IC from its performance (Stewart, 2001). Their methodology for measuring the value of intangible assets is based on the economic concept of 'production function,' where the firm's economic performance is considered to be generated by the three major classes of inputs: Physical, financial, and knowledge assets (Lev and Feng, 2001). The postulated relationship is:

$$
\text { Economic Performance }=\alpha(\text { Physical Assets })+\beta(\text { Financial Assets })+\delta(\text { Intangible Assets })
$$

Where $\alpha, \beta$ and $\delta$ represent the contributions of a unit of asset to the enterprise performance. Figure 14 shows the model for measuring IC.

${ }^{1}$ NCI Research is affiliated with the Kellogg Business School at Evanston, Illinois, USA. 


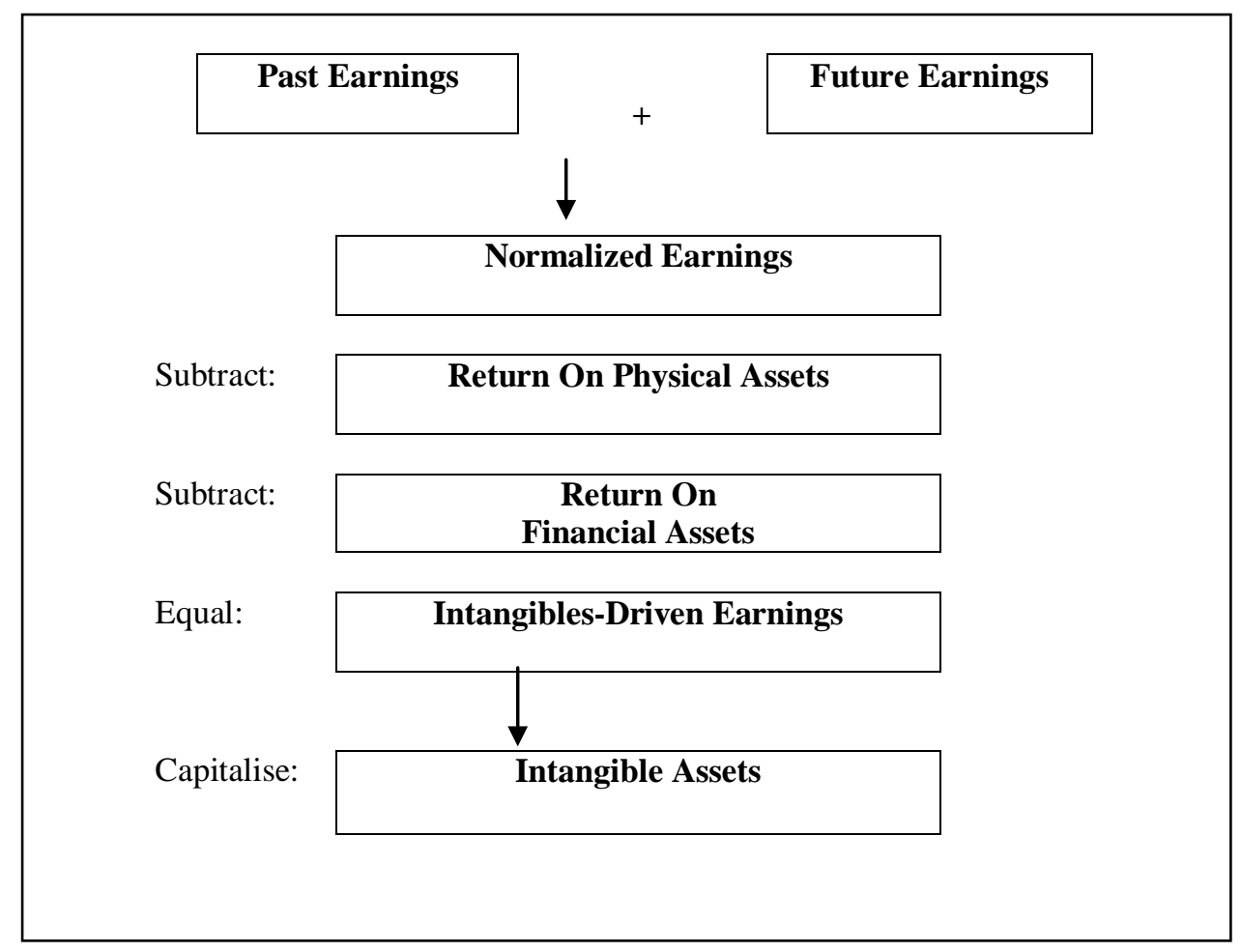

Figure 14 - The Lev Model (Lev and Feng, 2001)

The model starts with the company's 'normalised earnings' taken as the average of several (generally 3-5) historical years of reported net earnings (past earnings), and the same number of expected years earnings (future earnings) from analysts. The value of the IC can be deduced by subtracting the after-tax return on financial assets and the average after-tax return for physical assets. The resultant 'intangible-driven earnings' provide the value of intangible assets. Capitalising the expected stream of these earnings yields an estimate of 'intangible capital.' This method allows a more objective measure of IC and derives its value from the company earnings and other attributes found in a traditional balance sheet. However, the model also requires forecast earnings of firms to be available. These forecast may not be readily available for companies in some markets.

There are several other models contributed by the accounting fraternity. It is contended that to be decision-useful, an accounting model must look to the future. In this regard, cost-based accounting looks backwards and lacks relevance (Nash, 1998). Several models have been 
developed that may help accounting take account of decision-making usefulness, and therefore include some futurology (ibid., 1998). The various models are shown in Table I.

\begin{tabular}{|c|c|}
\hline \multicolumn{2}{|r|}{ Various Accounting Models } \\
\hline $\begin{array}{l}\text { Human Resource Costing \& } \\
\text { Accounting (HRCA) by } \\
\text { Johanson and Grojer (1998). }\end{array}$ & $\begin{array}{l}\text { Calculates the hidden impact of HR related costs which reduce a } \\
\text { firm's profits. Adjustments are made to the profit and loss statement. } \\
\text { IC is measured by calculation of the contribution of human assets } \\
\text { held by the company divided by capitalised salary expenditures. }\end{array}$ \\
\hline $\begin{array}{l}\text { Accounting for the Future } \\
\text { (AFTF) by Nash (1998). }\end{array}$ & $\begin{array}{l}\text { A system of projected discounted cash-flows. The difference between } \\
\text { AFTF value at the end and the beginning of the period is the value } \\
\text { added during the period. }\end{array}$ \\
\hline $\begin{array}{l}\text { Total Value Creation, } \\
\text { TVC }^{\text {TM }} \text { by McLean (1999). }\end{array}$ & $\begin{array}{l}\text { A project initiated by the Canadian Institute of Chartered } \\
\text { Accountants. TVC }{ }^{\mathrm{TM}} \text { uses discounted projected cash-flows to re- } \\
\text { examine how events affect planned activities. }\end{array}$ \\
\hline $\begin{array}{l}\text { The Value Explorer }{ }^{\mathrm{TM}} \text { and } \\
\text { Weightless Weights by } \\
\text { Andriessen and Tissen, } \\
\text { (2000); Andriessen (2001). }\end{array}$ & $\begin{array}{l}\text { Accounting methodology proposed for calculating and allocating } \\
\text { value to } 5 \text { types of intangibles: (1) Assets and endowments, (2) Skills } \\
\text { \& tacit knowledge, (3) Collective values and norms, (4) Technology } \\
\text { and explicit knowledge, (5) Primary and management processes. }\end{array}$ \\
\hline
\end{tabular}

\section{Table I - The Various Accounting Models}

In summary, several methodologies for measuring IC have been developed. These measuring techniques are still evolving. Bornemann et al. (1999) point out that standards for measuring and reporting IC are still in their infancy, confused and unstructured. This is quite normal for new concepts, and they suggest that a constructive approach is to focus on IC measures. Bontis (2001) argues that a paradigm requires actual findings from measured variables to confirm observed and expected events. He claims that like all business models advanced to date, IC models need to be tested for their defensibility as a new paradigm.

Caddy (2002) calls for greater focus to investigate current metrics used to determine their overall validity. Validation of IC measurement will improve the ability of organisations to draw meaningful conclusions about themselves from their own IC data, as well as make meaningful assessments of how well or otherwise they are doing when compared with other similar organisations (ibid). Mouritsen et al. (2001) state that IC report is different from reading a financial statement. This is because the IC statement is not regulated and based on specific requirements as in the case of the financial statements. The financial statements are an institutionalised report accepted and endorsed by accounting bodies worldwide (ibid.). 
Nevertheless, more objective methodologies are emerging that allow IC to be measured in a manner that can be applied.

\section{Applications of IC}

The previous section highlighted attempts to develop new reporting mechanisms that enable IC to be measured alongside traditional, quantifiable financial data (Johanson et al., 1999; M`Pherson and Pike, 2001). However, for IC to command the attention of management it must give companies a competitive edge and result in superior financial performance. There must be practical applications for the study of IC. From a strategic perspective, IC can be used to create knowledge that enhances a firm value. Marti (2001) notes:

Researchers in the areas of sustainable competitive advantages have come to the conclusion that the only thing that gives an organisation a competitive edge, the only thing that is sustainable, is what it knows, how it uses what it knows, and how fast it can know something new. The key role of knowledge as a source of competitive advantage is to produce intellectual capital in an efficient way.

Knowledge is a critical factor affecting an organisation's ability to remain competitive in the new global marketplace (Bollinger and Smith, 2001). Bollinger and Smith (2001) argue that organisations need to recognise knowledge as a valuable resource and develop a mechanism for tapping into the collective intelligence and skills of employees in order to create a greater organisational knowledge base.

According to Nonaka (1995), an organisation's knowledge is created through the interaction between tacit and explicit knowledge. Nonaka postulates four different modes of knowledge conversion. This is shown in Figure 15. 
Tacit

\begin{tabular}{|l|l|}
\hline $\begin{array}{l}\text { Tacit to Tacit - Vicarious learning, } \\
\text { by observing, mimicking and } \\
\text { practising. }\end{array}$ & $\begin{array}{l}\text { Explicit to Tacit - Real mastery of } \\
\text { knowledge and the internalisation } \\
\text { of the learned knowledge and } \\
\text { become shared skills. }\end{array}$ \\
\hline $\begin{array}{l}\text { Tacit to Explicit - Expressing } \\
\text { mental knowledge using } \\
\text { metaphors, analogies, concepts, } \\
\text { hypotheses or models that can be } \\
\text { articulated. }\end{array}$ & $\begin{array}{l}\text { Explicit to Explicit - Formalised } \\
\text { courses and learning through } \\
\text { documents, discussions and } \\
\text { computerised systems. }\end{array}$ \\
\hline
\end{tabular}

Figure 15 - Four Modes of Knowledge Conversion (Nonaka 1995)

For tacit to tacit conversion, an individual shares tacit knowledge directly with another. For example, an apprentice learns from a grand master by observation, imitation and practice. For explicit to explicit, individuals learn through attending formal training courses or learn from books and reports. An example of tacit to explicit is when a master craftsman articulates the foundations of his tacit knowledge and converts it into explicit knowledge. Explicit to tacit takes place when new explicit knowledge is shared and disseminated throughout an organisation. The interaction of tacit and explicit knowledge, when properly stimulated, can make a company's knowledge base grow exponentially. This is because knowledge is one of the few assets that grows most when shared. It is the key to enhance competitiveness (ibid).

Petrash’s (1996) proposes a six-phase model for the management of IC. The six phases are:

1. Portfolio - This is a an inventory in simple terms of the company's current IC. It is an identification of IC and determine if these are still active and find an internal business or cost centre that is willing to take ownership and pay the cost of maintaining it.

2. Classification - In this phase, IC is classified into three major categories: a) the business is using, b) the business will use, and c) business will not use.

3. Strategy - This is taking the IC portfolio and knowing how to utilise and integrate it into business strategy. An important objective of this phase is to identify the IC gaps between business strategy and the capabilities of the existing IC portfolio. This is where resources that are targeted toward creating IC can be focused. 
4. Valuation - In this phase, IC is valued or measured (with help from external consultant if necessary) and opportunities for licensing or sale to other companies are identified.

5. Competitive Assessment - This is about organising the IC and comparing it against competitors in order to evaluate such factors as dominance, breadth of coverage, opportunities and threats.

6. Investment - With an understanding of the value of existing IC, its competitive situation and the gaps, companies can then proceed to fill in those gaps between its portfolio and its strategy. This can be done via in-house development or through external acquisition.

Modern managers need to understand the changing environment, the emergence of the knowledge-based economy, what IC is and how to manage and harness it for greater competitiveness (ibid.).

Bontis (1998) conducted an empirical pilot study that explores the development of several conceptual measures and models regarding IC and its impact on business performance. A questionnaire that taps into the IC constructs, as well as business performance within the context of the conceptual model, was developed. The questionnaire has 63 items designed to measure four constructs (three constructs relating to IC plus performance). The study suggests reliable, significant and substantive causal links between dimensions of IC and business performance.

Using empirical analysis, Zhen et al. (1999) find that patent attributes are statistically associated with subsequent stock returns and market-to-book ratios. In general, companies that are innovating rapidly are more successful in product development and more competitive than companies that are relying on old technologies. The suggestion is that patent-based measures provide a useful tool for the investment analysis of technology and science based enterprises.

Under increasing competitive pressure, many companies are examining how they can manage their IC more efficiently. Civi (2000) argues that a company's knowledge management strategy 
should reflect its competitive strategy. This includes how it creates value for customers, how that value supports an economic model, and how the company's people deliver on that value. Also, competitive strategy must drive knowledge management strategy and executives must be able to articulate how knowledge that resides in the company adds value for customers (ibid.).

Carneiro (2000) examines knowledge management and its influence on innovation and competitiveness. He argues that knowledge management is a strategic tool and is a key resource for decision making, mainly for the formulation of alternative strategies. When knowledge is harnessed strategically, the company can formulate competitive strategies that integrate innovative products and new technological development to face its competitors. Combined with knowledge workers' adaptability and high-quality standards, knowledge can give sustainable advantages against competitors and offers alternative platforms for target markets.

Anell and Wilson (2002) propose the creation of prescripts for companies to gain competitive advantage. They argue that winning companies in the future will not be just 'learning' ones. They will be the ones with the ability to extract and codify knowledge into prescripts instead of attempting to store it in people or machines. This is similar to Nonaka's (1995) concept of transforming tacit knowledge to explicit knowledge in order for companies to internalise the expertise that is residing in the brains of their people.

Hurwitz et al. (2002) use Lev and Feng's (2001) methodology to determine the linkage between management practices, intangibles performance and stock returns. The major finding of their research is that a value stream based on intangibles performance is the most significant driver of stock returns. They find that this is true regardless of the industry or of a firm's strategy. The analysis shows that companies must manage their IC to generate excess returns on their tangible assets. 
Rylander and Peppard (2003) propose a concept which links competitive strategy, identity and IC that is deemed more suitable for knowledge-intensive companies competing in uncertain environments. The concept links the vision-based and values-based strategy (outlining what and where the company wants to be in the future) and the concept of identity (what the company is) to the IC resources of the company. Many of the most critical resources in a knowledge-intensive firm are IC resources like structures, processes, systems, culture, brands, competencies and relationships with customers. The financial and physical resources support the IC resources and are an integral part of a firm's strategy. The model describes the linkages between 'strategy' and 'resources' from an IC perspective that are to be mobilised to make the strategy happen. This is shown in Figure 16.

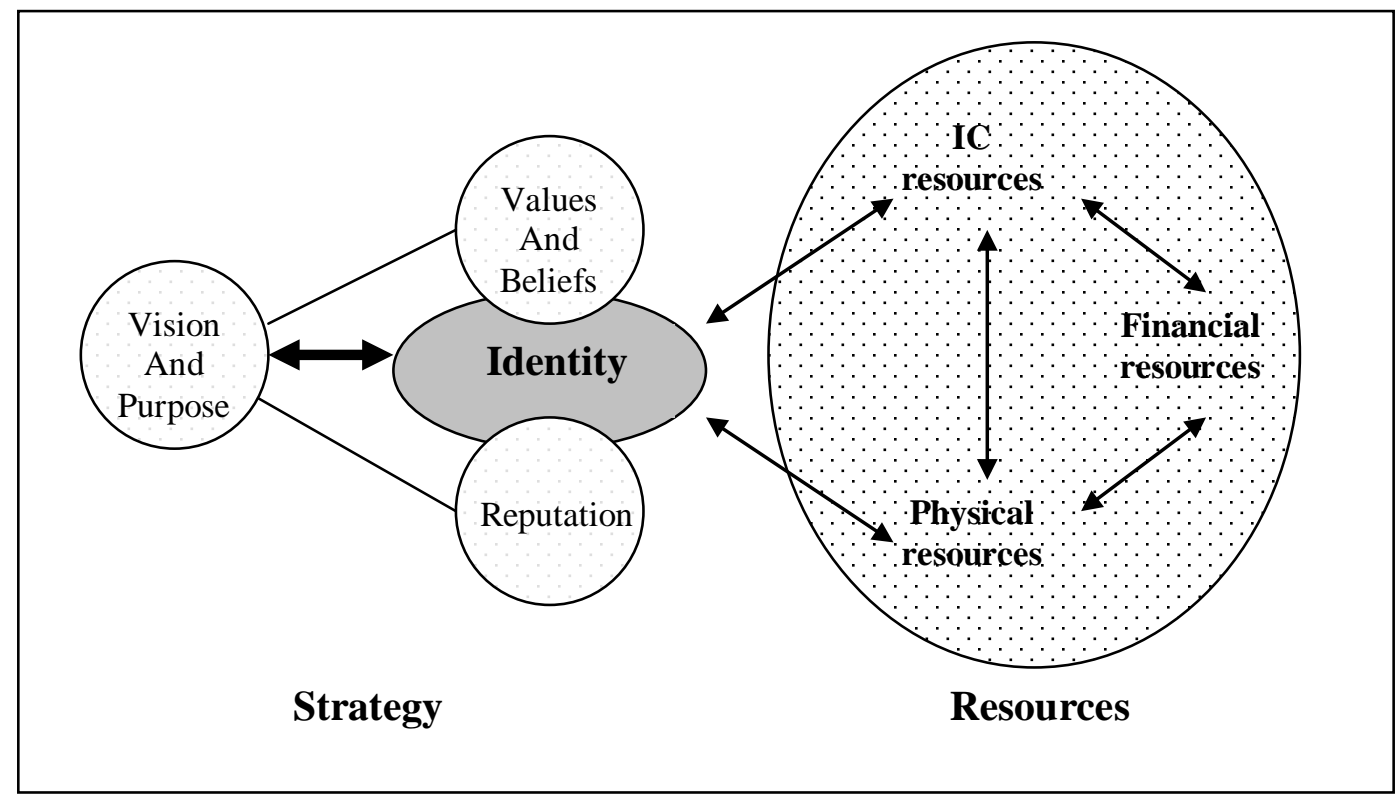

Figure 16 - Linking Competitive Strategy to IC (Rylander and Peppard 2003)

Mavridis (2004) uses the Pulic VAIC ${ }^{\text {TM }}$ method to analyze the data of Japanese banks. By analysing the human and physical capital of the Japanese banking sector and their impact on the banks' value-based performance, the study confirms the existence of significant performance between the banks.

Chen et al. (2005) also use VAICTM on Taiwanese listed companies and find IC to have a positive impact on a firm's market value and financial performance, and may be an indicator for future financial performance. Tan et al. (2007) apply VAIC ${ }^{\text {TM }}$ to Singaporean publicly listed companies and find that: IC and company performance are positively related; IC is correlated to 
future company performance; the rate of growth of a company's IC is positively related to the company's performance; and the contribution of IC to company performance differs by industry. Similarly, Kamath (2007) applies VAIC ${ }^{\text {TM }}$ to data of Indian banks and confirms the existence of vast differences in the performance of Indian banks in different segments.

Guimon (2005) conducts a comprehensive conceptual framework to analyze the impact of IC reporting in credit risk analysis. Wang (2005) uses the Balanced Scorecard (BSC) to study empirical relationships between a set of BSC indicators and the exchange ratios for a sample of 32 mergers and acquisitions of 14 financial holding companies. The BSC indicators explain as high as 90 percent of the variations of the exchange ratios. Wang and Chang (2005) investigate the impact of IC elements on business performance as well as the relationship among IC elements from a cause-effect perspective for Taiwanese information technology industry. Results show that IC elements directly affect business performance. Silvi and Cuganesan (2006) investigate the management of knowledge for competitive advantage and Martin-deCastro et al. (2006) also examine organisational capital for competitive advantage of a firm.

\section{Summary}

The study of IC has undergone a number of stages. According to Petty and Guthrie (2000), the first-stage efforts have typically focused on consciousness raising activities that strive to communicate the importance of recognising and understanding the potential for IC. The next stage of development has been one of consolidation that established research into IC as a legitimate undertaking and has sought to gather robust evidence in support of its further development (ibid.). A subsequent stage involves the search for appropriate measures of IC. Yet a further stage applies IC to company performance, including competitive advantage. This paper serves as a useful reference for anyone embarking on research into IC and it provides a succinct summary of the seminal works on this research area. 


\section{Bibliography}

Andriessen, D., (2001), "Weightless Wealth: Four Modifications To Standard IC Theory", Journal of Intellectual Capital, Vol. 2, Issue 3, pp. 204-214.

Andriessen, D. and Tissen, R., (2000), Weightless Wealth; Find Your Real Value in a Future of Intangible Assets, Financial Times and Prentice-Hall, London.

Anell, B.I. and Wilson, T.L., (2002), "Prescripts: Creating Competitive Advantage In The Knowledge Economy”, Competitiveness Review, Vol. 12, Issue 1, pp. 26-37.

Barsky, N.P. and Marchant, G., (2000), "The Most Valuable Resource - Measuring And Managing Intellectual Capital”, Strategic Finance, Vol. 81, Issue 8, pp. 58-62.

Bollinger, A.S. and Smith, R.D., (2001), "Managing Organisational Knowledge As A Strategic Asset”, Journal of Knowledge Management, Vol. 5, Issue 1, pp. 8-18.

Bontis, N., (1998), "Intellectual Capital: An Exploratory Study That Develops Measures And Models”, Management Decision, Vol. 36, Issue 2, pp. 63.

Bontis, N., (2001), “Assessing Knowledge Assets: A Review of The Models Used To Measure Intellectual Capital”, International Journal of Technology Management, Vol. 3, Issue 1, pp. 4160.

Bontis, N., Dragonetti, N.C., Jacobsen, K. and Roos, G., (1999), "The Knowledge Toolbox: A Review of The Tools Available To Measure And Manage Intangible Resources”, European Management Journal, 17, pp. 391-401.

Bornemann, M., Knapp, A., Schneider, U. and Sixl, K.I., (1999), "Holistic Measurement of Intellectual Capital", paper presented at the International Symposium Measuring and Reporting Intellectual Capital: Experiences, Issues, and Prospects, OECD, Amsterdam.

Brooking, A., (1996), Intellectual Capital, Thomas Business Press, London.

Caddy, I., (2002), "Issues Concerning Intellectual Capital Metrics And Measurement of Intellectual Capital”, Singapore Management Review, Vol. 24, Issue 3, pp. 77-83.

Carneiro, A., (2000), "How Does Knowledge Management Influence Innovation And Competitiveness?”, Journal of Knowledge Management, Vol. 4, Issue 2, pp. 87-99.

Chen, M.C., Cheng, S.J. and Hwang, Y.C., (2005), "An Empirical Investigation Of The Relationship Between Intellectual Capital And Firms' Market Value And Financial Performance", Journal of Intellectual Capital, Vol. 6, Issue 2, pp. 159-176.

Civi, E., (2000), “Knowledge Management As A Competitive Asset”, Marketing Intelligence \& Planning, Vol. 18, Issue 4, pp.166-174.

Danish Confederation of Trade Unions (DCTU), (1999), "Your Knowledge - Can You Book It?”, a paper presented at the International Symposium Measuring and Reporting Intellectual Capital: Experiences, Issues, and Prospects, OECD, Jun, Amsterdam.

Dzinkowski, R., (2000), “The Measurement And Management of Intellectual Capital: An Introduction”, Management Accounting, Vol. 72, Issue 2, pp. 32-36.

Edvinsson, L. and Malone, M., (1997), Intellectual Capital: Realizing Your Company's True Value By Finding Its Hidden Brainpower, Harper Collins, New York. 
Guimón, J., (2005), “Intellectual Capital Reporting And Credit Risk Analysis”, Journal of Intellectual Capital, Vol. 6, Issue 1, pp. 28-42.

Guthrie, J., (2001), “The Management, Measurement And The Reporting of Intellectual Capital”, Journal of Intellectual Capital, Vol. 2, Issue 1, pp. 27.

Haanes, K. and Lowendahl, B., (1997), "The Unit of Activity: Towards an Alternative to the Theories of the Firm, Strategy, Structure and Style, in Thomas, H. (Eds), John Wiley \& Sons Ltd, Copenhagen.

Hurwitz, J., Lines, S., Montgomery, B. and Schmidt, J., (2002), "The Linkage Between Management Practices, Intangibles Performance And Stock Returns”, Journal of Intellectual Capital, Vol. 3, Issue 1, pp. 51-61.

International Federation of Accountants (IFAC), (1998), “The Measurement and Management of Intellectual Capital”, International Federation of Accountants, New York.

Jacobsen, K., Hofman-Bang, P. and Nordby, R. Jr (2005), “The IC Rating ${ }^{\mathrm{TM}}$, Journal of Intellectual Capital, Vol.6. Issue 4, pp. 570 - 587.

Johanson, U. and Grojer, J.E., (1998), “Current Development In Human Resource Costing And Accounting Reality Present, Researchers Absent?”, Accounting, Auditing \& Accountability Journal, Vol. 11, Issue 4, pp. 495-504.

Johanson, U., Mårtensson, M. and Skoog, M., (1999), "Measuring And Managing Intangibles: Eleven Swedish Exploratory Case Studies", a paper presented at the International Symposium Measuring Reporting Intellectual Capital: Experiences, Issues, and Prospects, OECD, Jun, Amsterdam.

Joia, L.A., (2000), "Measuring Intangible Corporate Assets Linking Business Strategy With Intellectual Capital”, Journal of Intellectual Capital, Vol. 1, Issue 1, pp. 68-84.

Kamath, G.B., (2007), “The Intellectual Capital Performance Of The Indian Banking Sector”, Journal of Intellectual Capital, Vol. 8, Issue 1, pp. 796-123.

Kannan, G. and Aulbur, W.G., (2004), “Intellectual Capital: Measurement Effectiveness”, Journal of Intellectual Capital, Vol.5. Issue 3, pp. 389-414.

Kaplan, R.S. and Norton, D.P., (1992), "The Balanced Scorecard - Measures That Drives Performance", Harvard Business Review, Vol. 70, No. 1, pp. 71-79.

Leon, M.V.S., (2002), "Intellectual Capital: Managerial Perceptions of Organisational Knowledge Resources”, Journal of Intellectual Capital, Vol. 3, Issue 2, pp. 149-166.

Leliaert, P.J.C., Candries, W. and Tilmans, R., (2003), "Identifying And Managing IC: A New Classification”, Journal of Intellectual Capital, Vol. 4, Issue 2, pp. 202.

Lev, B. and Feng, G., (2001), "Intangible Assets: Measurement, Drivers, Usefulness", New York University, Apr.

Liebowitz, J. and Ching, Y.S., (2000), "Developing Knowledge Management Metrics for Measuring Intellectual Capital”, Journal of Intellectual Capital; Vol. 1, Issue 1, pp. 54-67.

Lowendahl, B., (1997), Strategic Management of Professional Service Firms, Handelshojskolens Forlag, Copenhagen. 
Luthy, D.H., (1998), “Intellectual Capital And Its Measurement”, Utah State University, Logan, Utah USA. Available online: http://www3.bus.osaka-cu.ac.jp/apira98/archives/htmls/25.htm.

Lynn, L.E., (1998), “The Management of Intellectual Capital: The Issues And The Practice”, Management Accounting, Issues Paper 16, Management Accounting Practices Handbook. Hamilton, Ontario: Society of Management Accountants of Canada.

Marti, J.M.V., (2001), “ICBS - Intellectual Capital Benchmarking System”, Journal of Intellectual Capital, Vol. 2, Issue 2, pp. 148-164.

Martín-de-Castro, G., Navas-López, J.E., López-Sáez, P. and Alama-Salazar, E., (2006), "Organizational Capital As Competitive Advantage Of The Firm", Journal of Intellectual Capital, Vol. 7, Issue 3, pp. 324-337.

Mavridis, D.G., (2004), “The Intellectual Capital Performance Of The Japanese Banking Sector”, Journal of Intellectual Capital, Vol.5. Issue 1, pp. 92 - 115.

McLean, R., (1999), “Accounting for The Creation of Value”, Canadian Institute of Chartered Accountants. Available online: http://cpri.matrixlinks.ca/tvc/Presentations/TVCPresent/index.htm.

Meritum, (2001), “Measuring Intangibles To Understand And Improve Innovation Management", Final Report, European Community. Available online: http://www.kunne.no/meritum.

Mouritsen, J., Bukh, P.N., Larsen, H.T. and Johansen, M.R., (2001), "Reading An Intellectual Capital Statement: Describing And Prescribing Knowledge Management Strategies”, Journal of Intellectual Capital, Vol. 2, Issue 4, pp. 359-383.

Mouritsen, J., Bukh, P.N., Larsen, H.T. and Johansen, M.R., (2002), "Developing And Managing Knowledge Through Intellectual Capital Statements”, Journal of Intellectual Capital, Vol. 3, Issue 1, pp. 10-29.

M'Pherson, P.K. and Pike, S., (2001), “Accounting, Empirical Measurement And Intellectual Capital”, Journal of Intellectual Capital, Vol. 2, Issue 3, pp. 246-260.

Nash, H.H., (1998), “Accounting for The Future”, Prospective Accounting Initiative. Available online: http://home.sprintmail.com/ humphreynash/indexback.htm.

Nonaka, I., (1995), The Knowledge Creating Company, Harvard Business Review on Knowledge Management, Harvard Business School Press, 1998, Boston, USA, pp. 21-45.

Oliver, J.L.H. and Porta, J.I.D., (2006), “How To Measure IC In Clusters: Empirical Evidence”, Journal of Intellectual Capital, Vol. 7, Issue 3, pp. 354-380.

Organisation for Economic Co-Operation And Development (OECD), (1999), "Guidelines And Instructions for OECD Symposium", International Symposium Measuring Reporting Intellectual Capital: Experiences, Issues, And Prospects, Jun, Amsterdam, Jun, OECD.

Petrash, G., (1996), "Dow's Journey To A Knowledge Value Management Culture", European Management Journal, Vol. 14, Issue 4, pp. 365-73.

Petty, P. and Guthrie, J., (2000), "Intellectual Capital Literature Review: Measurement, Reporting And Management”, Journal of Intellectual Capital, Vol. 1, Issue 2, pp.155-175.

Pulic, A., (1998), "Measuring The Performance of Intellectual Potential In Knowledge Economy”. Available online: http://www.measuring-ip.at/OPapers/Pulic/Vaictxt/vaictxt.html. 
Pulic, A., (2000), "VAICTM - An Accounting Tool for IC Management”. Available online: http://www.measuring-ip.at/Papers/ham99txt.htm.

Roos, J., Roos, G., Dragonetti, N.C. and Edvinsson, L., (1997), Intellectual Capital: Navigating The New Business Landscape, Macmillan Press, London.

Rylander, A. and Peppard, J., (2003), "From Implementing Strategy To Embodying Strategy: Linking Strategy, Identity And Intellectual Capital”, Journal of Intellectual Capital, Vol. 4, Issue 3, pp. 316.

Seetharaman, A., Sooria, H.H.B.Z. and Saravana, A.S., (2002), "Intellectual Capital Accounting And Reporting In The Knowledge Economy”, Journal of Intellectual Capital, Vol. 3, Issue 2, pp. 128-148.

Silvi, R. and Cuganesan, S., (2006), "Investigating The Management Of Knowledge For Competitive Advantage: A Strategic Cost Management Perspective", Journal of Intellectual Capital, Vol. 7, Issue 3, pp. 309-323.

Stewart, T.A., (1997), Intellectual Capital: The Wealth of New Organisations, Nicholas Brealey Publishing Ltd, London.

Stewart, T.A., (2001), “Accounting Gets Radical”, Fortune, Vol. 143, Issue 8, pp. 184-194.

Sveiby, K.E., (1997), The New Organisational Wealth: Managing And Measuring Knowledge Based Assets, Berrett Koehler, San Francisco, USA.

Sveiby, K.E., (2001), “A Knowledge-Based Theory of The Firm To Guide In Strategy Formulation”, Journal of Intellectual Capital, Vol. 2, Issue 4, pp. 344-358.

Sveiby, K.E., (2002), “Methods for Measuring Intangible Assets”. Available online: http://www.sveiby.com/articles/IntangibleMethods.htm.

Tan, H.P., Plowman, D. and Hancock, P., (2007), "Intellectual Capital And Financial Returns Of Companies”, Journal of Intellectual Capital, Vol. 8, Issue 1, pp. 76-95.

VanderKaay, S., (2000), "Measuring The Vital Signs of Intellectual Capital", CMA Management, Vol. 74, Issue 4, pp. 18-21.

Wang, W.C., (2005), "An Evaluation Of The Balanced Scorecard In Equity Valuation: The Case Of Exchange Ratio In The M\&As Of Taiwan's Financial Industry", Journal of Intellectual Capital, Vol. 6, Issue 2, pp. 206 - 221.

Wang, W.Y. and Chang, C.F., (2005), "Intellectual Capital And Performance In Causal Models: Evidence From The Information Technology Industry In Taiwan", Journal of Intellectual Capital, Vol. 6, Issue 2, pp. 222-236.

Williams, S.M., (2000), “Is A Company’s Intellectual Capital Performance And Intellectual Capital Disclosure Practices Related? Evidence From Publicly Listed Companies From The FTSE 100”, University of Calgary, Alberta, Canada, Available online: http://www.measuringip.at/Papers/Paper1.pdf.

Zhen, D., Lev, B. and Narin, F., (1999), "Science And Technology As Predictors of Stock Performance”, Financial Analysts Journal, Vol. 55, Issue 3, pp. 20-32. 